\title{
Cross-Reactivity of New Insulin Analogs in Insulin Assays
}

\section{carta ao editor}

\section{José Gilberto H. Vieira \\ TERESINHA T. TACHIBANA \\ Cláudia M. FERRER \\ ANDRÉ F. REIS}

Diabetes Center, Fleury Institute, São Paulo, SP.

\section{TO THE EDITOR}

TSULIN MEASUREMENT HAS important applications in clinical practice. Besides providing information about insulin dynamics in patients with diabetes mellitus and insulin resistance, it has a special place in the differential diagnosis of hypoglycemic conditions. Insulin measurement is based in immunoassay techniques, initially radioimmunoassay (RIA) and nowadays immunometric assays. One of the advantages of the transition of RIA to immunometric assay was the superior specificity of the latter, resulting in lower values (1). Specificity of the new immunometric assays is, in fact, quite strict, with almost no cross-reaction with proinsulin or $\mathrm{C}$ peptide. In the last years, several insulin analogues, with different profiles of action based on point modifications of the insulin molecule, have been described (2). To define their cross-reaction in the new immunometric assays is of evident clinical importance. We studied four preparations of insulin analogs: (a) insulin aspart (NovoRapid, Novo Nordisk), with aspartic acid substitution for proline in B28; (b) lispro insulin (Humalog, Eli Lilly), with an exchange between B28 (proline) and B29 (lysine); (c) glargine insulin (Lantus, Aventis), with glycine instead of asparagine in position A2 l, and two additional arginine residues at the end of B chain; and (d) detemir insulin (Levemir, Novo Nordisk), with a fatty acid chain linked to the lysine residue B29. All insulin preparations were obtained commercially as $100 \mathrm{U} / \mathrm{mL}$ preparations. The assay studied was an immunofluorometric assay provided by PerkinElmer, based on two highly specific monoclonal antibodies that show some cross-reaction only with Des 64-65 split proinsulin (10\%). The results obtained are depicted in figure 1 . The only

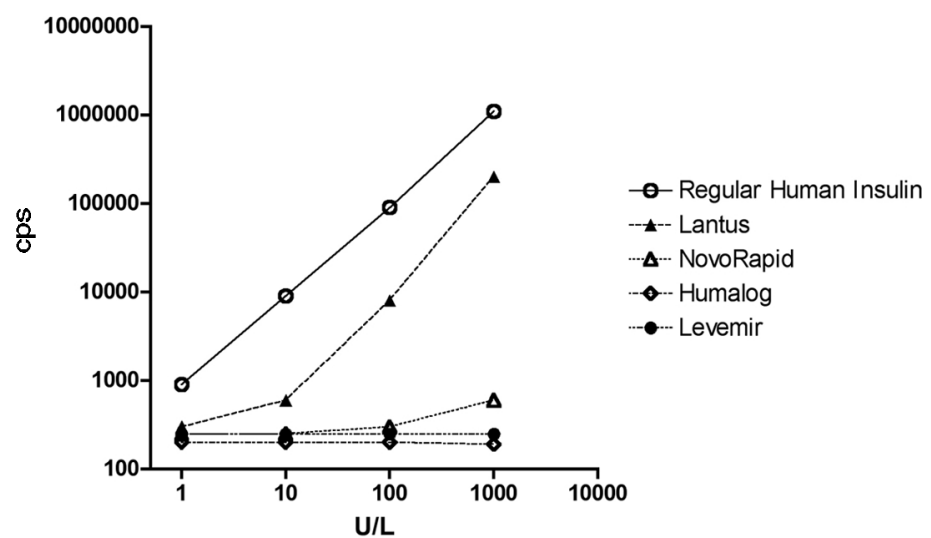

Figure 1. Study of the cross-reactivity of four insulin analogs in the PerkinElmer immunofluorometric assay. The reference preparation (Regular human insulin) showed a response curve that was superimposable with the standard provided with the assay kit.

Cps= counts per second. 
insulin analog that showed cross-reactivity was glargine insulin $(13.5 \%)$, others were all below $1 \%$. This definition is very important because recent publications have shown that the different assays available are not uniform in terms of cross-reactivity with the new insulin analogs $(3,4)$. Some assays show high cross-reactivity with all analogs studied, and some almost none. To our knowledge, this is also the first study describing cross-reactivity with the new analog preparation detemir insulin. To know what you are, or can be measuring, is one of the basic principles in order to provide an assay result of the higher diagnostic sensitivity and specificity.

\section{REFERENCES}

1. Vieira JGH, Nishida SK, Lombardi MT, Tachibana TT, Obara $\mathrm{LH}$, Dalbosco IS, et al. Comparison of the determination of insulin by monoclonal antibody-based immunofluorometric assay and by radioimmunoassay. Braz J Med Biol Res 1995;28:537-43.
2. Hirsch IB. Insulin analogues. N Engl J Med 2005;352:17483.

3. Owen WE, Roberts WL. Cross-reactivity of three recombinant insulin analogs with five commercial insulin immunoassays. Clin Chem 2004;50:257-9.

4. Morioyama M, Hayashi N, Ohyabu C, Mukai M, Kawano S, Kumagai S. Performance and cross-reactivity from insulin analogs with the Architect insulin assay. Clin Chem 2006;52:1423-6.

Endereço para correspondência:

José Gilberto H. Vieira

Av. General Valdomiro de Lima 508

04344-070 São Paulo, SP

E-mail: jose.vieira@fleury.com.br 